\title{
Urban heritage and cultural tourism development: A case study of Valletta's role in Malta's tourism
}

John Ebejer

Institute for Tourism Travel and Culture, University of Malta, Malta

Email: john.ebejer@um.edu.mt

For the published version of this peer reviewed paper

refer to Journal of Tourism and Cultural change

\begin{abstract}
Despite significant potential for cultural tourism, the predominant form of tourism in Malta is sun and sea. This paper evaluates Malta's potential for cultural tourism with a focus on Valletta, a fortified historic city that overlooks the Grand Harbour. Valletta's rich urban heritage and historic narrative makes it ideal for the development of a more cultureoriented tourism. The paper explores how, over more than half a century of tourism activity in Malta, culture and heritage retained a secondary role. Since the mid-nineties, Malta's tourism policy shifted with culture and heritage being given greater importance, even if sun and sea tourism remained a priority. Public and private investment brought about changes in Valletta that made it more amenable to cultural activity and tourism. Although European Capital of Culture Valletta 2018 provides new opportunities for cultural tourism to Malta, it is unclear whether this will bring a lasting legacy for Malta's tourism. This Valletta case study shows that, for destinations with an established form of tourism, the development of cultural tourism meets with difficulties, in spite the presence of a rich urban heritage.
\end{abstract}

Keywords: urban heritage, cultural tourism, Valletta, tourism development, Malta's tourism

Acknowledgments: I would like to thank Dr. Andrew Smith and Prof. John Tunbridge for their comments on an earlier draft of this paper. Thanks also to the anonymous reviewer for the feedback. 


\section{Urban heritage and cultural tourism development:}

\section{A case study of Valletta's role in Malta's tourism}

\section{Introduction}

The use of urban heritage for tourism development is common practice in many cities. Where available, urban heritage facilitates a city's efforts to generate employment and increase revenue through increased cultural tourism. These efforts are dependent on the context and the specific circumstances of the city including its past tourism development and the quality of the urban heritage.

Malta is a small Mediterranean island whose capital, Valletta, is a fortified historic city with extensive urban heritage. A discussion on the development of Malta's tourism provides useful insights in how cultural tourism fares in a context where the dominant form of tourism was, and still is, sun and sea. Past and present cultural tourism activity in Malta have been shaped by three factors. First, for more than half a century Malta's tourism activity was based largely on sun and sea and it is only since the year 2000 that there have been efforts to promote other forms of tourism. Second, access to Malta is almost solely dependent on air travel. This necessitates an approach to tourism that is different from that of a city with a large hinterland. The act of travelling to Malta represents a definitive break from home. Third, Malta has a very rich urban heritage, much of which is focused in Valletta. The urban heritage could potentially provide a good basis for the development of cultural tourism. These three elements combine to create a unique set of circumstances and are recurrent themes in a discussion of Malta's tourism development, a discussion that is developed in the first part of the paper. 
The second part of the paper considers Valletta's role in past and contemporary tourism in the Maltese Islands. The city's rich urban heritage is characterised by interesting streetscapes and squares, with the occasional monumental building. A combination of urban heritage, history and narrative greatly enhance Valletta's potential for cultural tourism. In spite of this, Valletta played a marginal role in the development of Malta's tourism. This paper considers why this is the case and discusses Valletta's changing role in Malta's tourism.

\section{Reflections on cultural and heritage tourism}

It is sometimes assumed that the cultural tourist represents someone who is highly motivated to travel for cultural reasons. McKercher and du Cross (2003) argue that this assumption is flawed as the centrality of cultural motives in driving destination choice varies significantly amongst tourists. For some it represents the central reason to travel. For many tourists engaging in culture, it is a secondary reason and may well have played no part in the choice of destination. McKercher and du Cros (2003, p.47) distinguish between five types of cultural tourists. At one end of the continuum, there are the 'purposeful cultural tourists' who are highly motivated to travel for cultural reasons and who subsequently have deep experiences. At the other end, there are tourists for whom culture plays no role in their decision to travel and who have a shallow experience. These are referred to as 'incidental cultural tourists'.

In recent years, the Malta Tourism Authority has updated their regular traveller survey to better identify different types of cultural tourists. The MTA survey categorisation of cultural tourists is based on respondents' replies to the main motivations for visiting Malta. Cultural tourists are classified into three. The first category is 'the greatly motivated'. These are people who travel to a destination specifically because of its 
cultural opportunities. Then there are 'the motivated in part' cultural tourists who are persons who travel both because of cultural opportunities and other motivations such as leisure, sun and sea (Valletta 2018 Foundation, 2016). A third category is the 'accidental' cultural tourist who visits a destination for a reason other than culture but who then actively engages in a cultural activity at the destination (Sultana \& Attard, 2016). These different typologies suggest that a discussion on cultural tourism cannot be limited to the 'purposeful' or the 'greatly motivated' cultural tourist because these are just part of a broader tourism cultural activity that takes place at the destination.

An issue that merits attention is how cultural tourism relates to the destination's established sun and sea tourism. Ashworth and Tunbridge (2005) identify three different scenarios. The first is one where new tourism forms are an effective 'supplement' to mass markets with heritage tourism being seen as an add-on to the existing dominant tourism. The second is one where the two forms of tourism are developed in 'parallel', with heritage catering for a separate market alongside but substantially different from the existing sun and sea tourism market. The third scenario involves new tourism acting as a 'substitute' for mass tourism with a deliberate, centrally directed, shift from one form of tourism to its replacement by another. Heritage tourism in Malta tends towards the first 'supplement' scenario (Bramwell, 2007), as illustrated and discussed in the next section.

\section{The role of heritage and culture in Malta's tourism development - a history}

Malta is an archipelago with a population of less than half a million. With independence in 1964 and the end of the British military bases in Malta in 1979, there was an urgent need for Malta's economy to diversify. Tourism was the obvious choice because of Malta's pleasant weather and extensive coastline. A typical holiday consisted of a package deal based around a week or two week stay at a hotel along the coast. The 
growth in Malta's volume of tourist arrivals was matched by poor product development and a series of problems such as environmental degradation, infrastructural overloading, over-dependence on a single source market and seasonal fluctuations with underemployment during the winter (Markwick, 1999).

In the 1970s, the tourism industry in Malta became complacent, partly because of Malta's unique advantage of being an English-speaking Mediterranean nation (English is widely spoken and it is Malta's second official language). There was little or no effort to diversify away from the apparently dependable British market. Yet a severe downturn in tourist arrivals in the early 1980s exposed this over-dependence on British mass-market tourism (Foxell and de Trafford, 2010).

Most of the tourism accommodation was developed in the coastal resorts northwest of the Grand Harbour thus resulting in very little accommodation being located in or within easy reach of Valletta (Tunbridge, 2008). Until the 1990s Malta's accommodation sector grew in line with the demands of tour operators who persisted in selling Malta as a sun and sea holiday destination, peaking in July and August, with little else to offer during the other months of the year. (Pollacco 2003). In 1985, an incentive for UK-based tour operators was introduced as a temporary measure but which then kept being renewed until year 2000. This was a preferential currency exchange rate (a forward buying rate). At the time $85 \%$ of Malta's tourism business was generated by the large tour operators. The Maltese government was concerned that the removal of the incentive would induce the large multi-nationals to shift their business elsewhere in the Mediterranean and this could have resulted in a collapse of Malta's tourism. Although the support sustained visitor numbers it was counterproductive because Malta's image remained predominantly that of a sun and sea destination (Theuma, 2006). 
In 1988, the first tourism policy plan for Malta recommended the upgrading of the infrastructure, achieving a more heterogeneous tourist market and lengthening the tourist season. The development of cultural tourism was one of the suggested strategies. Repositioning Malta as a destination for cultural tourism was, however, not considered feasible because this potential segment was too small compared to the overall masstourism market. The advice was for Malta to promote combined cultural and sun holidays (Foxell and de Trafford, 2010). Since the early nineties, the Maltese government sought to diversify the destination tourist product to include cultural and heritage tourism, with these often seen as niche tourism products. (Benur and Bramwell, 2015). There was a growing realisation that Malta was no longer competitive in the basic sun and sea package because of larger and often newer destinations that could handle much larger volumes. What had fuelled the growth of the Maltese industry in previous decades could no longer sustain the growth and development of the industry.

In spite the initial efforts, Malta's image right up to 2000 was ....;

.... that of a sun destination that differed very little from other Mediterranean resorts; with a warm climate, island setting with friendly and hospitable people, strong historical links, language familiarity with main source market (UK), low standard of overall accommodation, catering largely aimed at lower socio-economic groupings, low quality of service/training. (Pollacco, 2003, p. 74)

In 2002, a process of 'repositioning' was set in motion. Malta product was redefined and became more reliant on Malta's distinctive comparative advantage, away from the more traditional sun and sea product to one that also incorporates its rich heritage. A twopronged tourism strategy was adopted encompassing mainstream tourism and identified niche tourism sectors. Key heritage sites were upgraded to improve their interpretation, accessibility, conservation and promotion. Malta is orientated towards the double package 
of 'sun-sea and 'culture-heritage' with each image being applied to specific target market (Metaxas, 2009).

Malta has an unusually rich heritage because of many layers of history and cultural influences (Bramwell, 2007, Ashworth \& Tunbridge, 2004). The urban heritage is dispersed throughout the islands but with notable concentrations in the fortified historic cities of Vittoriosa, Mdina and Valletta (Markwick, 2017a).

With greater competition from destinations in the Mediterranean and further afield, the use of heritage for tourism purposes was considered and advocated in the Tourism Masterplan of 1988 and the Strategic Plan for Tourism 2002-2004 (Malta Tourism Authority, 2002). Maltese official sources often expressed the desire of moving up-market away from a beach resort holiday industry towards an industry based upon heritage and culture. There is however limited evidence of a radical restructuring of tourism markets. Between 2007 and 2011, the number of culture and heritage tourists increased in absolute terms (from 158,000 to 185,000 ), but remained fairly stable at $14.5 \%$ of the total holiday visits to Malta (Markwick, 2017a).

In 2006, low cost airlines (LCC) started to operate to Malta. This resulted in sustained increases in tourism numbers over the past decade reaching 1.8 million tourists in 2015 (Malta Tourism Authority, 2016). It could be argued that the lower fares, increased flexibility, increased capacity and the access to new markets provided by LCCs would assist the development of a viable city break market. In this context, Valletta being a World Heritage Site would be a strong pull factor (Smith, 2009). It is useful to compare tourist motivation in 2006, when there were no LCCs, with those of 2010 (Ministry for Tourism, 2012). The percentage of tourists with a sole motivation of 'culture and history' remained constant at around $15 \%$. This suggests that LCC passengers are no more likely to be motivated by culture than passengers who visited Malta pre-2006. For LCC 
passengers, culture and heritage provide added attractions to visit but is not a primary motivation to visit Malta. LCCs brought more tourists to Malta but, rather than being more motivated by history and culture, LCC passengers are still primarily motivated by climate (63\% in 2006 and $66 \%$ in 2010) (Ministry for Tourism, 2012).

Apart from the introduction of LCC, another change this past decade has brought about major changes in the tourism industry worldwide, including Malta. This was the widespread use of internet technology as a means of promoting and booking holidays. Similar to other destinations, independent internet booking and low cost airlines have eroded the package holiday market. The net effect is that Malta's tourism industry is "more diversified, less seasonal and less dependent on tour operator business" (Ministry for Tourism, 2012). The individual travel tourist (as opposed to tour operator tourist) rose from $33 \%$ of the total in 2006 to $55 \%$ of the total in 2010 (Ministry for Tourism, 2012).

The introduction of the euro in 2008 increased Malta's attractiveness as a tourism destination because of the removal of exchange rate costs. Apart from reduced expenses, tourists from euro-zone countries are relieved from the annoyance of exchanging money at borders and can also make price comparison when making spending money at the destination (EU Commission, n.d.). Santana-Gallego et al (2016) claim that the impact of the euro on intra-Eurozone tourism, including Malta's was substantially positive.

Government tourism policy describes 'culture' as a key asset for Maltese tourism. The policy advocates "focus on our cultural offering as it contributes to attract tourists who are interested in heritage, in our local traditions, in contemporary art and creativity and in all those spheres that create cultural distinctiveness for the Maltese islands." (Ministry for Tourism, 2012). It proposes numerous culture and heritage related initiatives including for example the promotion of village cores and village festivals. Compared to previous tourism policy plans, there is significant emphasis on cultural events and activities, 
including encouraging visits to Malta specifically for such events. This makes the European Capital of Culture (ECoC) in 2018 even more relevant for Malta's tourism. Policy direction is for heritage and culture to become tourist attractors rather than just addons to a summer and winter sun leisure holiday. In spite of declared policy intentions and changes to the tourism industry, there is no detectable shift away from sun and sea towards cultural tourism. Valletta's and Malta's urban heritage remain largely an add-on to a beach resort holiday (Ashworth and Tunbridge, 2016). This section has set the context with a discussion of Malta's tourism and the role of heritage and culture in its development. The next section will focus on Valletta and its role in Malta's tourism.

\section{Valletta's role in tourism}

\subsection{A brief introduction to Valletta}

Valletta is at the heart of an urban conurbation that spreads for several kilometres around the two harbours, Grand and Marsamxett (Figure 1). Valletta is both a capital city and a port city. Since its beginnings, it was the main entry point into Malta, with ships docking in the Grand Harbour alongside Valletta. Right up to the nineteen fifties, virtually all goods and people coming from overseas entered Malta through Victoria Gate, the City's gate facing the Grand Harbour. Malta's independence in 1964 reinforced Valletta's role as the islands' political and administrative capital. The city provides the nation's most important transport, commercial, administrative and financial hub (Smith, 2010). Valletta has remained a leading retail centre even if there is increased competition from new commercial centres and new forms of retailing. It is also an important location for private sector offices. Valletta is an important national symbol and also a place that is 
experienced directly by a large proportion of Maltese on a regular basis, giving rise to potential conflicts between its symbolic and lived functions (Smith, 2010).

With an area of just 55 hectares, Valletta is unusually small for a nation's capital (Smith 2010). The decline in population over several decades has now stabilised at around 6,000 (Dingli, 2016). Valletta is home to several parishes, each of which is the centre of community life (Ebejer, 2016a). There is a strong popular culture amongst the community, normal day-to-day activities and celebrations of the residents adding colour and depth to the cultural experience of the city (Theuma, 2004). In the 1970s, cafeterias and restaurants no longer opened in the evenings and cinemas closed down. Referring to Valletta's night time activity, Fabri (2016, p. 19) laments the way that "what once was the most busy and sought-after meeting place in Malta, was now turning into a ghost town." This trend has been reversed in recent years with the opening of numerous bars and restaurants, many of which capitalise on the historic features of Valletta's buildings (Fabri, 2016).

\subsection{Valletta's history and narrative}

Many tourism experiences are dependent on the availability and communication of narratives. (Chronis, 2012). Narratives are 'constructed' by people and they may, or may not, be based on historical fact. Human activity is rooted in place and therefore narratives about people are also narratives about places. The combination of the lived experience with the myth produces a uniquely personal tourist narrative (Rickly Boyd, 2009). Valletta's history provides a narrative spanning hundreds of years from before 1565 to today.

The two periods in history that left the most lasting mark on Malta and its urban landscape were the Knights of St. John (1530-1798) and the British (1800-1964). Each is 
linked to an important historic episode, namely the Great Siege of 1565 and Malta's role in Second World War (1940-44). Ashworth and Tunbridge (2004, p. 15) note how "both are highly dramatic events, easily understood, with few historical ambiguities and with clear cut personification through heroes and villains." Both involve a global struggle with which tourists can easily identify. For these reasons, Ashworth and Tunbridge (2004, p. 15) refer to these two historical events as "almost an ideal tourism product". There are sites in Valletta that enable the visitor to see tangible evidence of these two remarkable narratives, thereby making the narrative more powerful and real and thus the experience more interesting and enjoyable. When standing at the Upper Barrakka looking over the Grand Harbour, one elderly British tourist explained how he visualised World War II enemy action over allied ships in port (Ebejer, 2017). Another example is a small chapel in Fort St. Elmo where it is believed that the Knights took the last stand before the fort fell to the invading Turks in the Great Siege of 1565. Fort St. Elmo also includes defensive structures built by the British that were used in the defence of Valletta and the Grand Harbour during the Second World War.

A dominant element in Valletta's narrative is the sea. The city owes its very existence to its location on a peninsula separating two natural harbours. The sea features prominently in many historical events and hence in many Valletta narratives, including the two world events referred to previously. Over the years, the sea impinged on the culture, the economic activity and even on the way residents live their lives (Valletta 2018 Foundation, 2012). Being a peninsula, the sea is visible from most parts of the City, including the inner streets. This is a constant reminder, to tourists in particular, of the historical and cultural links of the city with the sea that surrounds it.

For tourists, the fortifications that surround the city are a further reminder of Valletta's narrative. This is a fortified city built to keep out invaders. It was actively 
engaged in warfare in two important episodes in history. The fortifications' historicity sustain and support the narratives that emerge from the urban heritage within the city walls. Bruce and Creighton (2006) refer to several instances across Europe where town walls present dilemmas for communities and heritage agencies because of potential differing interpretations based on ideological or ethnic grounds. This has not been the case in Valletta or any of Malta's walled towns making the narrative of fortifications largely unproblematic. According to Ashworth and Tunbridge (2005), Malta has a highly cohesive national identity making the use of its heritage resources free from internal cultural schism. The physicality of the buildings and structures are a reflection of the culture, a matter that is discussed in the next section.

\subsection{Culture and urban heritage in Valletta}

For Maltese people, Valletta is strongly associated with culture because of the cultural venues $^{1}$ and also because of the history and the built heritage. Valletta was declared European Capital of Culture in October 2012 thus allowing for a 6-year run-up to Valletta 2018. Although the designation includes all of Malta and Gozo, and not just Valletta itself, it is inevitable that Valletta will be the focus of cultural activities. It also provides the opportunity to develop a more culture-oriented image for Valletta with international tourists.

Valletta has a distinctive identity because of the built heritage that is present across the City. Identity is reinforced by well-defined edges around its perimeter namely the shoreline on three of four sides and the fortifications on all four sides. The fortifications surrounding the city are impressive both for their extent as well as for their height. The

\footnotetext{
${ }^{1}$ The main cultural venues in Valletta are the Manoel Theatre, the Mediterranean Conference Centre, the Centre for Creativity, the Museum of Fine Arts, the National Museum of Archaeology, St. John's Co-Cathedral and the open air performance space at City Gate, Pjazza Teatru Rjal.
} 
urban fabric of Valletta communicates a Maltese identity as well as an international one (Smith and Ebejer, 2012). Valletta's streetscapes are characterised by distinctive timber balconies and extensive use of Maltese stone. On the other hand, the many administrative, residential, cultural and religious buildings that dominate the cityscape are visible reminders of the Order of St. John. The iconic views of Valletta from across the Grand Harbour, and also those across Marsamxett Harbour, emphasise the City's distinct identity (Speake, 2017). The form of the town and its fortifications together with the meanings and associations are vital contributors to Valletta's sense of place.

Valletta's iconic nature was recognised with its designation as a World Heritage Site by UNESCO in 1980. It owes its status "to being a complete, intact, late renaissance, planned walled city begun in 1566 by the ruling Knights of St John after the lifting of the dramatic Ottoman siege of 1565" (Ashworth and Tunbridge, 2016, p. 1). Contrary to many other walled towns that have become 'time-frozen' such as Mdina, Conwy, Urbino and Visby (Bruce and Creighton, 2006), Valletta is a city that constantly needs to adapt to changing needs, within the constraints set by the need to conserve the built heritage.

Urban heritage is not just about the buildings but also about the urban spaces within the historic setting. Valletta's grid-iron street layout was based on the utopia of new town planning concepts that were in vogue in the mid-sixteenth century. Torpiano (2016, p. 9) refers to Valletta as a beautiful city and to its abundance of interesting public urban spaces, many of which were designed with people in mind. He notes that there are many places "where the play of light and shade creates interest, where change in scale, from the restrained to the monumental, creates surprise and delight. There are many spaces for people to discover and enjoy." Ashworth and Tunbridge (2004, p. 16) notes how the city confronts the visitor with sets of contrasts, with "alternating land and water, the works of man and nature, a compact enclosed denseness and vistas of open space, of the cool dark 
shady streets within and hot harsh sunlit water, without, of noisy human bustle and peace, of yellows and blues." Valletta's uniform street pattern is adorned with statues, imposing civic and ecclesiastical buildings, and monumental city gates (Smith, 2010). Many streets and gardens at the periphery of the city provide quiet enclaves offering open vistas of the harbours. Several streets in Valletta are stepped because of their steep incline. Steps inhibit streets being taken over by the car, and therefore their particular character has survived more than other places (Torpiano, 2016). Valletta has more similarities with a medieval fortress than with a contemporary city because of the intact city walls and coherent architecture (Smith, 2010).

Up to the 1990's Valletta was characterised by deteriorating buildings and poor quality urban spaces, superimposed with an ever increasing number of visitors and tourists. There was very little public and private investments in the city. As from the mid-1990's public investment in the city picked up mostly focused on restoration projects but still significantly less than what was required. The Museum of Archaeology, the Centre for Creativity and the new cruise passenger terminal below the Floriana bastions (completed in 1998, 2000 and 2005 respectively) were the only three notable projects for Valletta for several decades. The lack of public investment was mirrored by a lack of private investment in the City, creating a gradual yet steady downward spiral and increased dilapidation in many parts of Valletta.

Former Prime Minister Dr. Lawrence Gonzi² referred to a '20 year project for Valletta' (Gonzi, 2016) that had three main objectives namely to instil a sense of national pride by upgrading the capital city, to make it attractive for people to live and work and to make Valletta “our own permanent Capital of Culture." The project initiated in 2004

\footnotetext{
${ }^{2}$ Dr. Lawrence Gonzi was Malta's Prime Minister from 2004 to 2013. During his premiership, he took a particular interest in Valletta projects, especially the City Gate project.
} 
included major interventions most of which were along the axis that runs from City Gate to Fort St. Elmo.

As from 2008, pedestrian areas were extended ${ }^{3}$ to include other important spaces in the city most notably St. George's Square, Merchants Street and Castille Square. The City Gate project did not just involve the buildings but also the creation of pedestrian spaces around the buildings. These projects created spaces that are more amenable for pedestrians allowing visitors to better appreciate Valletta's urban heritage. A series of projects were implemented to improve access to the City. The Upper Barrakka lift was installed to connect Valletta's Grand Harbour shoreline to the centre of Valletta. Other Valletta transport-related projects were a new public ferry service across the Grand Harbour, the introduction of controlled vehicle access and a park and ride facility.

Another major project was the rehabilitation of Fort St. Elmo and its reuse as a museum and a ramparts walk. Fort St. Elmo is strategically located at the tip of the Valletta peninsula and overlooks the entrances to the harbours. The primary objective of the project, completed in 2015, was to restore and bring back to life historic buildings and structures and to do so in a manner which was financially sustainable. The project "converted what was previously a war machine into a machine for tourism, leisure, education and the appreciation of heritage." (Ebejer, 2016b, p. 6). Other notable projects are the ongoing restoration of St. John's Co-Cathedral and the museum extension of the same cathedral, due for completion in 2018 (Malta Independent, 2016).

The City Gate project completed in 2015 is the last important part of a much wider series of urban regeneration projects over the last decade. (Ashworth \& Tunbridge, 2016). The site consists of three parts namely (i) City Gate, (ii) the new Parliament building on the former Freedom Square and (iii) an open air performance space within the opera house

\footnotetext{
${ }^{3}$ Up until then, only Republic Street was pedestrianised. This is the main shopping street, leading on from City Gate.
} 
ruins, now referred to as Pjazza Teatru Rjal. Each has a remarkable symbolic and cultural significance. The site is the interface between the compact historic city and the wider urban agglomeration that stretches around the Grand Harbour. It has enormous symbolic significance being at the entrance to Malta's capital and main historic city (Ashworth \& Tunbridge, 2016). As Smith and Ebejer (2012, p.145) state: "gates act as points of arrival and departure and mark the boundary between here and there, within and without and inside and outside." The siting of a Parliament building at the entrance to Valletta is also replete with meaning. The Maltese Parliament is one of just 27 EU-national parliamentary assemblies across the European Union. It is the legislative body of the smallest member in the EU, with Malta having a voice in the EU which is disproportionate to its size (Ebejer, 2016a). The opera house at the entrance to the city was demolished in 1942 during World War II. There were pressures for the opera house to be rebuilt, out of a sense of nostalgia for the past, when opera was perceived to be central to Malta's cultural and social life. Government decision was to have an open air performance space within the ruins of the old opera house. The decision was highly controversial with many arguments put forward for and against the rebuilding of the opera house (Smith and Ebejer, 2012).

In recent years, there was also investment in open air cultural events in Valletta, the most notable being Notte Bianca. The first Notte Bianca took place in 2006, and it is now a well-established event in Malta's cultural calendar. Historic buildings, churches, museums and shops remain open till late and streets come alive with recitals, opera, jazz, poetry readings, exhibitions, dance, walk tours, street theatre and more. It is part of a long term project of bringing night time activity back into the Capital and has been a particularly successful example of an event programmed in the public realm at night (Smith, 2016). 
Fabri (2016) lists as many as 16 different festivals that are held in Valletta throughout the year, most of which saw their beginnings in the last fifteen years. Some target a national audience (Malta Arts Festival, Science in the City and Malta Fashion Week). Others attract an international clientele (International Jazz Festival, International Valletta Film Festival, Valletta Baroque Festival, Malta Mediterranean Literature Festival). Valletta offers many diverse and interesting open air spaces. Staging with historic buildings backdrop gives added value to the events. Valletta also hosts events that are more closely linked to local culture (Carnival, religious feasts and Holy Week celebrations). More than just events, these are opportunities for Valletta residents and Maltese to creatively communicate their culture and way of life (Fabri, 2016).

As from 2005, public sector investment in Valletta increased markedly in capital projects and in an extended programme of events. This leveraged some private investment in Valletta's historic properties, initially only to a limited degree. Several buildings were restored and rehabilitated into residences, offices or shops. More recently, private investors realised the opportunities offered by a revitalized Valletta. Private sector investment picked up pace mostly with investments in boutique hotels, short term tourism rental and food and drink establishments (Markwick, 2017b). In spite of these developments, there are still pockets in Valletta where the dilapidation of buildings persists.

\subsection{Future prospects of cultural tourism activity in Valletta}

In 2013, the main motivators for visiting Malta were 'agreeable climate' (57\%), 'novelty of the destination' (47\%) and 'history and culture' (39\%) (Malta Tourism Authority, 2014). Visitors to Valletta are not limited to tourists who listed history and culture (i.e. $39 \%$ of the total) as a motive for their Malta visit, but also includes other 
tourists who chose Malta for other reasons. Even if just 39\% list 'history and culture' for a Malta visit, as many as $91 \%$ of tourists to Malta spend some time in Valletta (Sultana \& Attard, 2016, p. 7). Whatever the motive for a Malta visit, most tourists make it a point to visit and spend some time in Valletta. A Valletta locality survey (Valletta 2018 Foundation, 2016) reveals that the city provides for a positive tourist experience with high satisfaction ratings for most aspects of its product offer, including the rich cultural heritage and the city's vantage points and outward views. Respondents who visited cultural and historic attractions in Valletta were highly satisfied with the variety available, with the overwhelming majority attributing an above average rating (97\%). Despite weaknesses in basic amenities and upkeep, many tourists thoroughly enjoyed their visit of Valletta and would willingly recommend it to family and friends. On presentation and valorisation of cultural and historic sites the satisfaction levels were also high at $87 \%$. These findings are further confirmation of Valletta's immense potential for cultural tourism.

Less than 8 per cent of tourists to Malta stay in or close to Valletta (Malta Tourism Authority, 2014) but this percentage is set to increase albeit slightly in the coming years because of several new boutique hotels in Valletta. This is a positive development for Malta's tourism because it increases choice and increases the potential for the 'city break' market. There are also an increasing number of residences in Valletta offered for peer-topeer accommodation (such as $\mathrm{AirBnB}$ ). It is estimated that there are 4,000 properties across Malta and Gozo advertised on AirBnB, with a fourfold increase in just two years (Times of Malta, 2017a). Living within a historic context gives added value for cultureoriented tourists and offers guests the chance to have a more 'local' experience by living more like a local, interacting with the host and neighbours (Guttentag, 2015). An added benefit of tourist accommodation in historic areas is that they generate more activity, including in the evenings. In recent years there have been more restaurants and bars 
opening in Valletta. Their initial focus was on lunchtime to cater for Valletta's office workers, but now most cater for both daytime and weekend evenings.

Tourists staying in Valletta/Floriana exhibited a relatively high interest in history and culture. One in four indicated culture as a main motivator for their decision to visit Malta. This compares to just 11 per cent for the rest of the islands. Similarly, tourists staying in Valletta/Floriana have a higher participation rates in cultural activity when compared with tourists staying in other parts of Malta. (Valletta 2018 Foundation, 2016). In this context, cultural activities includes visits to museums, churches and historical buildings as well as attendance to live performance events and festivals. Markwick (2017a) contends that Malta already has a well-developed cultural tourism focused largely on three World Heritage Sites including Valletta and its many historic sites and museums. She notes however that there is considerable untapped potential for Valletta's enhanced role in the development of cultural tourism to Malta.

In this decade, there are two developments that are likely to give an enhanced international profile to Valletta, namely the completion of City Gate project and Valletta European Capital of Culture 2018. Both are in synch with Malta's brand shift towards heritage and culture. The extent to which these will impinge on Valletta's international profile and on tourism is dependent on how Maltese authorities capitalise on the opportunities that these two important developments offer. With the City Gate project, the elements that generate interest are many (Malta Independent, 2015). The development is at the entrance of a historic fortified city designated as a UNESCO World Heritage Site. The project is designed by international architect Renzo Piano includes Malta's national Parliament. Possibly because of the controversies before and during construction, Maltese authorities seem reluctant to push forward the new Parliament building, City Gate and Pjazza Teatru Rjal as buildings and places to be proud of. 
Preparations for Valletta European Capital of Culture 2018 has been ongoing since 2011. Valletta 2018 offers opportunities for more effective use of culture and heritage to enhance the scope and extent of Malta's cultural tourism. This could be achieved either through the intensification of the existing heritage base and/or diversification with a wider offer of cultural attractions (Markwick, 2017a). International exposure is an integral part of being Cultural Capital and this in turn provides numerous opportunities for marketing and promotion of Valletta and of Malta. On the other hand, achieving these objectives seems problematic because of difficulties in the organisation, with local artists (Times of Malta, 2017c) and the ECoC monitoring panel (Times of Malta, 2017b) expressing significant concerns. Although ECoC provides new opportunities for cultural tourism to Malta, it is unclear whether this will bring a lasting legacy for Malta's tourism.

This past decade there have been improvements in Valletta's urban heritage and public spaces most notably with the City Gate project, the rehabilitation of Fort St. Elmo and the pedestrianisation of Valletta's main urban spaces. A rich urban heritage, more and better visitor attractions, increased tourism accommodation, a busy events calendar and revitalised evening activity are all Valletta-based factors that sustain high levels of tourism activity in the city. Increased tourism activity generates private sector investment in the restoration of historic buildings thus improving streetscapes and reducing the sense of dereliction in some streets. On the other hand, it is debatable whether higher levels of tourism activity will, in the long term, be beneficial to Valletta's social fabric and popular culture. Discussions on Valletta often refer to the declining population (Dingli, 2016) and to the risk of dilution of the City's social life. Reasons for the population decline are complex and diverse (Ebejer, 2016a) but today there is the added reason of more inconveniences caused by night time activity from bars and restaurants. Gentrification is another process of change that is perceived to be a threat to the city's social life, even if it 
brings in much needed investment in the restoration of historic properties. The buying up of properties in Valletta by foreigners began in the nineties but it has gained momentum in the last decade or so. Around one every ten residents are foreigners (Dingli, 2016). The vitality of local community life has tourism implications because the daily life of the city and its community is part of the attraction (Theuma, 2004). Further depletion of Valletta's social and cultural life will negatively impact Malta's cultural tourism because some tourists have a "desire to get to know or in some ways be involved in the lives of local residents" (Ebejer, 2017, p. 90).

\section{Conclusion}

Urban heritage in its raw form is of limited benefit to cultural and heritage tourism. It needs to be restored, interpreted, brought into viable use and presented in a way that enables the tourist appreciate the cultural and aesthetic value. This requires substantial investments largely because of the high cost of rehabilitating historic buildings. In the first years of Malta's tourism industry, the City's potential for tourism was not utilized as a policy favouring mass tourism based on sun and sea persisted. There was little investment in urban heritage. Short term political consideration in favour of mass tourism took precedence over reasoned policy choices in favour of a more culture-oriented tourism.

Because of its history and urban heritage, Valletta's potential for tourism is significant. From the mid-nineties onwards, there was more talk about developing cultural tourism but with it came the realisation that significant amounts of money was required to bring the tourism product up to standard. Malta's tourism policy shifted with culture and heritage being given greater importance, even if sun and sea tourism remained a priority. Inevitably the policy shift brought with it more awareness of Valletta's tourism potential. European funding made it possible for the upgrading of Malta's tourism product including 
urban heritage and cultural resources. Valletta greatly benefited from these funds with investments in historic buildings, fortification, upgrading of museums and the creation of new visitor attractions. Public funding acted as leverage for private funding, and many historic private properties were rehabilitated and brought into use. These investments made Valletta more amenable to culture and tourism.

Global changes in the way the tourism industry operates impacted on the nature and dynamics of Malta's tourism industry. Low cost airlines and independent internet booking have made travelling easier and cheaper resulting in a more diversified and less seasonal industry. Another force of change is the increased use of peer-to-peer accommodation, the impact of which is now gradually emerging. More research is required to evaluate the impacts of low cost airlines and peer-to-peer accommodation, as Malta's tourism continues to evolve due to these and other forces.

In absolute terms the number of cultural tourists have increased, even if in relative terms the proportion of culture-motivated Malta visits remains largely unchanged at around $15 \%$. On the other hand, more than $91 \%$ visit Valletta. A tourist visit to Valletta is by its very nature cultural. This suggests that cultural tourism activity in Malta is largely based on the 'incidental cultural tourist'. Because of European Capital of Culture Valletta 2018, the number of culture-motivated tourists to Malta will increase in the short term. In the longer term, it is not possible to predict whether these increases will be sustained. Much depends on Valletta 2018's ability to build up a legacy and also on numerous other factors that impinge on Valletta and on Malta's tourism. 


\section{References}

Ashworth, G. (1995) Managing the Cultural Tourist. In G. Ashworth and A. Doetvorst (eds.) Tourism and Spatial Transformations. Wallingford: CAB International.

Ashworth, G. and J. Tunbridge, (2000), The Tourist- Historic City: retrospect and prospect of managing the heritage city, Amsterdam: Pergamon.

Ashworth, G. and J. Tunbridge, (2004). Malta Makeover: prospects for the realignment of heritage, tourism and development. URSI Report 304, Urban and Regional Studies Institute, University of Groningen.

Ashworth, G. and J. Tunbridge (2005). Moving from Blue to Grey Tourism - Reinventing Malta. Tourism Recreation Research, 30(1), 45-54.

Ashworth, G. and S. Page (2011). Urban tourism research: Recent progress and current paradoxes. Tourism Management, 32, 1-15

Ashworth G. and J. Tunbridge (2017): Multiple approaches to heritage in urban regeneration: the case of City Gate, Valletta, Journal of Urban Design, 22(4), 494-501.

Benur, A.M. and B. Bramwell (2015). Tourism product development and product diversification in destinations. Tourism Management, 50, 213-224.

Bramwell, B. (2007) 'Complexity, interdisciplinary and growth management: the case of Maltese resort tourism', in S. Agarwal and G. Shaw (eds) Managing Coastal Tourism Resorts, Clevedon: Channelview, 73-89.

Bruce, D and O. Creighton (2006). Contested Identities: The Dissonant Heritage of European Town Walls and Walled Towns. International Journal of Heritage Studies, 12 (3), May, 234 254

Chronis, A. (2012). Tourists as Story-Builders: Narrative Construction at a Heritage Museum, Journal of Travel \& Tourism Marketing, 29:5, 444-459.

Dingli, A (2016) Closing address by the Mayor of Valletta. Valletta Alive Foundation Seminar: Valletta Beyond 2020, 48-49. 9 April, Malta. Retrieved from https://www.um.edu.mt/library/oar//handle/123456789/17856

Ebejer, J. (2013) The quality of urban spaces in Valletta and their relevance to tourism. University of Malta international seminar: Regenerating Sicilian and Maltese waterfronts: 
Perspectives from two Mediterranean islands. $25 \mathrm{July}$, Malta. Retrieved from https://www.um.edu.mt/library/oar/handle/123456789/14832

Ebejer, J. (2016a). Regenerating Valletta : a vision for Valletta beyond 2020. Valletta Alive Foundation Seminar: Valletta Beyond 2020. 35-44. 9 April, Malta. Retrieved from https://www.um.edu.mt/library/oar/handle/123456789/17857

Ebejer, J (2016b) Developing project concepts for historic sites: Lessons learnt from Fort St. Elmo project. Symposium of European Walled Towns. Netherlands, 30 September. Retrieved from https://www.um.edu.mt/library/oar/handle/123456789/15012.

Ebejer, J. (2017). The tourist experience of historic places. LAP Lambert Academic Publishing.

EU Commission, Directorate-General for Economic and Financial Affairs (n.d.) Benefits of the euro for Malta. Retrieved from http://ec.europa.eu/economy_finance/publications/pages/publication7333_en.pdf

Fabri, V. (2016) Valletta: a Leisure City or a City of Culture? Valletta Alive Foundation Seminar: Valletta Beyond 2020, 19-23. 9 April, Malta. Retrieved from https://www.um.edu.mt/library/oar//handle/123456789/17856.

Torpiano, A. (2016). Spaces for People: Lessons from Valetta. Valletta Alive Foundation Seminar: Valletta; Beyond 2020, 4-18. 9 April, Malta. Retrieved from https://www.um.edu.mt/library/oar//handle/123456789/17856.

Foxell E. and A. de Trafford (2010). Repositioning Malta as a cultural heritage destination. International journal of culture, tourism and hospitality research, 4(2), 156-168.

Gonzi, L. (2016). Valletta: The Pride of what makes us a Maltese and European Nation. Valletta Alive Foundation Seminar; Valletta; Beyond 2020, 45-47. 9 April, Malta. Retrieved from https://www.um.edu.mt/library/oar//handle/123456789/17856

Guttentag, D. (2015) Airbnb: disruptive innovation and the rise of an informal tourism accommodation sector, Current Issues in Tourism, 18:12, 1192-1217.

Malta Independent (2015). Renzo Piano's city gate project 'enhances Valletta's international image' says Valletta Alive, 9 May.

Malta Independent (2016). St John's Co-Cathedral Museum Extension projected to be completed by 2018, 7 August. 
Malta Tourism Authority (2002). Strategic Plan 2002-2004. Valletta.

Malta Tourism Authority (2014), Market Research Analysis Year 2013: Results of a survey carried out between January to December 2013. Retrieved from

file:///C:/Users/user/Downloads/Profile_of_the_Tourist_Visiting_Malta_in_Year_2013_A.pdf.

Malta Tourism Authority (2016), Tourism in Malta 2015. Retrieved from

file:///C:/Users/user/Downloads/MTA_Statistical_Report(F)2016_Edition.pdf.

Markwick, M. (1999) Malta's tourism industry since 1985: Diversification, cultural tourism and sustainability. Scottish Geographical Journal, 115(3), 227-247.

Markwick M. (2017a) Valletta ECoC 2018 and cultural tourism development, Journal of Tourism and Cultural Change, 1-23

Markwick, M. (2017b) Creative clusters in the regeneration of Valletta and the cultural politics of Strait Street. Urban Research \&Practice, 1-24.

McKercher, B., and du Cros, H. (2003). Testing a cultural tourism typology. International Journal of Tourism Research, 5 (1) 45-58.

Metaxas, T. (2009). Place Marketing, Strategic Planning and Competitiveness: The Case of Malta. European Planning Studies, 17(9), September.

Ministry for Tourism, Culture and the Environment (2012) Tourism Policy for the Maltese Islands 2012-16, Draft for consultation, February, Valletta.

Mitchell, J. (2003) Looking Forward to the Past: National Identity and History in Malta. Identities: Global Studies in Culture and Power, 10:3, 377-398.

National Statistics Office, Malta (2014). Cruise Passengers: Q4/2013. News Release 013/2014. Pollacco, J. (2003) In the national Interest. Malta:Fondazzjoni Tumas Fenech.

Rickly Boyd J. (2009) The Tourist Narrative. Tourist Studies 9(3) pp 259-280.

Santana-Gallego, M., F. Ledesma-Rodríguez and J. Pérez-Rodríguez (2016). The euro effect: Tourism creation, tourism diversion and tourism potential within the European Union. European Union Politics. 17(1), 46-68. 
Smith, A. (2009) Effects of low cost airlines on efforts to develop cultural heritage tourism, Anatolia. 20(2), 289-306.

Smith, A. (2010) The role of national identity and tourism in city planning: the case of Valletta, Urban Research \& Practice, 3(1), 63-84.

Smith, A. (2016). Events in the City: Using Public spaces as events venues. London; Routledge.

Smith, A. and J. Ebejer (2012). Outward versus inward orientation of island capitals: the case of Valletta, Current Issues in Tourism, 15:1-2, 137-152.

Speake, J. (2017). Urban development and visual culture: Commodifying the gaze in the regeneration of Tigne Point, Malta. Urban Studies, 54(13), 2919-2934.

Sultana, T. and Attard M. (2016). Measuring the impact of ECoC Valletta 2018 on travel motivations and behaviour of tourists in Malta. Retrieved from http://tsf2016venice.enit.it/images/articles/Papers_Forum/5.2_Measuring\%20the\%20impact\%20 of $\% 20 \mathrm{ECoC} \% 20$ Valletta\%202018\%20on\%20Travel\%20Motivations\%20and\%20Behaviour\%20 of\%20Tourists\%20in\%20Malta.pdf.

Times of Malta (2017a, March 9). 3,824 properties on AirBnB . Times of Malta. Retrieved from https://www.timesofmalta.com/articles/view/20170309/business-news/3-824-properties-onAirBnB.641900.

Times of Malta (2017b, July 4) European Commission seeks V18 explanation on high-profile dismissals. Times of Malta. Retrieved from https://www.timesofmalta.com/articles/view/20170704/local/commission-seeks-v18-explanationon-high-profile-dismissals. 652342.

Times of Malta (2017c, July 23) 70 artists voice serious concerns on V18 foundation. Times of Malta. Retrieved from https://www.timesofmalta.com/articles/view/20170723/local/70-artistsvoice-serious-concerns-on-v18-foundation.653868

Theuma, N. (2004) Tourism, Culture and Cultural Tourism in Malta: The Revival of Valletta. In B. Bramwell (ed.) Coastal Mass Tourism. Clevedon: Channel View, 292-306.

Theuma, N. (2006) Malta: Re-imaging the Mediterranean Destination. In D. R. Hall, M.K. Smith, B. Marciszewska (Eds.), Tourism in the New Europe: The Challenges and Opportunities of EU Enlargement. CABI, 213-223. 
Tunbridge, J.E. (2008). Malta: Reclaiming the Naval Heritage? International Journal of Heritage Studies, 14: 5, 449-466

Valletta 2018 Foundation (2012), Imagine 18: Final Application for the Title of European Capital of Culture: Bid Book, September

Valletta 2018 Foundation. (2016). The Impacts of Valletta 2018: 2016 Research. Theme 4: The Tourist Experience. Retrieved from http://valletta2018.org/wp-content/uploads/2017/03/The-TouristExperience-Theme-4-2016-1.pdf. 